\title{
KIAT WIRAUSAHAWAN YANG SUKSES TERHADAP PELUANG MAHASISWA UNTUK BERWIRAUSAHA
}

\author{
Oleh: \\ Tedy Ardiansyah ${ }^{1}$ \\ Prasetio Ariwibowo ${ }^{2}$ \\ Khoirul Umam ${ }^{3}$ \\ Dosen Universitas Indraprasta PGRI \\ Email:teddyappi@gmail.com ${ }^{1}$
}

\begin{abstract}
ABSTRAK
Tujuan penelitian ini untuk mengetahui kiat pelaku usahawan yang sukses, dan adanya hubungan kiat pelaku usahawan sukses terhadap motivasi mahasiswa berwirausaha. Sedangkan urgensi penelitian meliputi anatara lain: Sebagai indicator awal untuk mengukur kualitas pendidkan kewirausahaan, Kontribusi untuk membentuk jaminan mutu pendidikan kewirausahaan, referensi untuk membangun karakter pendidikan kewirausahaan dan bahan referensi bagi penelitian selanjutnya serta dapat memberikan kontribusi positif bagi pengembangan ilmu dan pengetahuan bidang manajemen pada khususnya. Metode penelitian menggunkan pendekatan kuantitatif survey dimana instrument yang digunakan berupa angket, teknik sampling yang digunakan bersifat probability dengan metode sampling acak. Sample dilakukan di 3 universitas yaitu Universitas Nasional, Universitas Bakrie dan Universitas Thamrin. Kesimpulan yang didapatkan dari seluruh uji yang dilakukan secara garis besar mempunyai hubungan yang positif dimana kiat wirausahawan mempunyai pengaruh terhadap peluang mahasiswa untuk berwirausaha

Kata kunci: Kiat, Wirausahawan, Berwirausaha, Sukses, Mahasiswa
\end{abstract}

\section{A. PENDAHULUAN}

Dalam lima tahun belakangan ini usaha-usaha kecil mendapat perhatian yang sangat besar. Mereka memiliki daya survival yang sangat tinggi dan terbukti mampu mengatasi pengangguran serta berperan besar dalam perekonomian Indonesia.

Data dari Biro Pusat Statistik (BPS) mengeluarkan statistik tahun 2012 menyangkut UMKM, dimana jumlah UMKM 56, 5 Juta dengan pertumbuhan jumlah UMKM $2.41 \%$, sedangkan jumlah tenaga kerja UMKM yang mana menciptakan lapangan kerja adalah 107, 6 juta dengan pertumbuhan jumlah tenaga kerja UMKM adalah 5,83\%, sumbangan PDB UMKM 1,504 Milyar dengan pertumbuhan sumbangan PDB UMKM adalah 9,90\% dan terakhir. Nilai ekspor UMKM adalah 208 Milyar dengan pertumbuhan nilai ekspor UMKM 11\%

Usaha-usaha Mikro dan kecil ini memiliki daya survival tinggi karena mereka tumbuh secara alamiah. Ibarat pohon di dalam hutan, akarnya menghunjam dalam ke tanah dan batangnya kokoh menjulang kelangit. Walaupun bisnisnya overcrowded, tapi pohon-pohon ini mengakar dan hidup berdampingan dengan ekosistem di sekitarnya. Mereka saling memberi kehidupan 
Tabel 1.1

Perkembangan UMKM dari data BPS

\begin{tabular}{clcc}
\hline \multicolumn{3}{c}{ Perkembangan UMKM dari data BPS } \\
\hline 1 & Jumlah UMKM & Unit & 56534592 \\
2 & Pertumbuhan Jumlah UMKM & Persen & 2,41 \\
3 & Jumlah Tenaga Kerja UMKM & Orang & 107657509 \\
4 & Pertumbuhan Jumlah Tenaga Kerja UMKM & Persen & 5,83 \\
5 & Sumbangan PDB UMKM (harga konstan) & Rp. Miliar & 1504928,20 \\
6 & Pertumbuhan sumbangan PDB UMKM & Persen & 9,90 \\
7 & Nilai Ekspor UMKM & Rp. Miliar & 208067,00 \\
8 & Pertumbuhan Nilai Ekspor UMKM & Persen & 11,00 \\
\hline \multicolumn{4}{c}{ Sumber $:$ Badan Pusat Statistik (2016) }
\end{tabular}

Usaha kecil juga menghadapi berbagai permasalahan, seperti kendala modal, sumber daya manusia, sikap pemerintah yang berubah-ubah, lokasi usaha, persaingan, perkembangan teknologi, dan sebagainya.

Dari hal kendala tersebut, langkah demi langkah dijalankan dan dilalui sehingga seluruh rintangan dapat dilalui dan kesuksesan pun didapat, hal inilah yang menjadi bagian kesuksesan dari wirausahawan. Berdasarkan latar belakang tersebut maka penting bagi peneliti untuk mengetahui dan mengidentifikasikan faktor-faktor yang mempengaruhi hubungan kiat pelaku usaha yang sukses terhadap motivasi mahasiswa berstrategi wirausaha.

Adapun permasalahan yang akan dijawab dalam penelitian ini adalah sebagai berikut: Seberapa Efektif pengaruh kiat pelaku usahawan yang sukses terhadap peluang mahasiswa untuk berwirausaha?; Bagaimanakah hubungan antara pengaruh kiat pelaku usahawan yang sukses terhadap peluang mahasiswa untuk berwirausaha?

\section{B. TINJAUAN PUSTAKA Kewirausahaan}

Hal yang paling dasar adalah memahami dahulu arti dari kewirausahaan, (Robert D. Hisrich, Michael P. Peters, 2008), Kewirausahaan (entrepreneurship) adalah proses penciptaan sesuatu yang baru pada nilai menggunakan waktu dan upaya yang diperlukan, menanggung risiko keuangan, fisik, serta risiko sosial yang mengiringi, menerima imbalan moneter yang dihasilkan, serta kepuasan dan kebebasan pribadi.

Definisi ini menekankan empat aspek dasar dari menjadi seorang pengusaha. Pertama, Kewirausahaan melibatkan proses penciptaan-menciptakan suatu nilai baru. Penciptaan haruslah mempunyai nilai bagai pengusaha dan bagi pelanggan untuk siapa citptaan tersebut dikembangkan. Pelanggan dapat berupa (1) pasar pembeli organisasi untuk inovasi bisnis, (2) administrasi rumah sakit untuk prosedur atau peranti lunak baru, (3) calon murid untuk sebuah kursus baru atau bahkan kuliah kewirausahaan, atau (4) pengguna untuk jasa baru yang disediakan oleh sebuah badan nirlaba. Kedua, Kewirausahaan menuntut sejumlah waktu dan upaya yang dibutuhkan. Hanya mereka yang melalui proses 
kewirausahaan yang menghargai sejumlah besar waktu serta upaya yang dibutuhkan untuk menciptakan sesuatu yang baru dan menjadikannya beroperasi. Ketiga dari definisi tersebut melibatkan penghargaan menjadi seorang pengusaha. Penghargaan yang paling penting adalah kebebasan, lalu kepuasan pribadi. Bagi seorang pengusaha pencari laba, penghargaan moneter adalah juga penting. Bagi beberapa pengusaha pencari laba, uang menjadi indikator tingkat sukses yang dicapai. Menanggung risiko yang dibutuhkan adalah aspek akhir dari kewirausahaan. Karena tindakan membutuhkan waktu, sedangkan hasil di masa yang akan datang tidak dapt diprediksi, maka hasil dari tindakan tersebut mengandung ketidakpastian. Lebih jauh lagi, ketidakpastian ini kemudian dieprkuat dengan sifat dasar yang khas dalam tindakan wirausahawan, seperti penciptaan produk baru, jasa baru, usaha baru dan lain sebagainya. "Pengusaha harus memutuskan untuk bertindak bahkan ketika menghadapi ketidakpastian rentang hasil dari indkannya. Selanjutnya Pengusaha akan merespons dan menciptakan perubahan melalui tindakan kewirausahaan (entrepreneurial action), sedangkan tindakan wirausaha mengacu pada perilaku sebagai bentuk tanggapan atas keputusan yang didasarkan pada pertimbangan ketidakpastian mengenai peluang yang mungkin untuk mendapatkan keuntungan".

Wirausahawan harus memahami lebih dahulu mengenai Asas, Prinsip dan Tujuan Pemberdayaan UMKM, dimana ini akan membantu dalam proses kewirausahaan sehingga tidak adanya hambatan dalam mencapai suatu (Leonardus Saiman, 2014) bahwa Asas-asas Usaha Mikro, Kecil dan Menengah (UMKM) harus mengacu pada BAB II, Pasal 2 beserta penjelasannya pada Undang-Undang Nomor 20 tahun 2008 tentang Usaha Mikro, Kecil dan Menengah (UMKM), asas-asas UMKM diantaranya:

1. Asas kekeluargaan, yaitu asas yang melandasi upaya pemberdayaan UMKM sebagai bagian dari perekonomian nasional yang diselenggarakan berdasarkan atas demokrasi ekonomi dengan prinsip kebersamaan, efiseinsi berkeadilan, berkelanjutan, berwawasan lingkungan, kemandirian, keseimbangan, kemajuan, dan kesatuan ekonomi nasional untuk kesjahteraan seluruh rakyat indonesia.

2. Asas demokrasi ekonomi, yaitu pemberdayaan UMKM diselenggarakan sebagai kesatuan dari pembangaunan perekonomian nasional untuk mewujudkan kemakmuran rakyat.

3. Asas kebersamaan, yaitu asas yang mendorong peran seluruh UMKM dan dunia usaha secar bersama-sama dalam ketiatnnya untuk mewujdukan kesejahteraan rakyat.

4. Asas efisiensi berkeadilan, yaitu asas yang mendasari pelaksanaan pemberdayaan UMKM dengan mengedepankan efiseinsi berkeadilan dalm usaha untuk mewujudkan iklim usaha yang adil, kondusif, dan berdaya saing.

5. Asas keberlanjutan, yaitu asas yang secara terncana mengupayakan berjalannya proses pembanganunan melalui pemberdayaan UMKM yang dilakukan secar berkesinmbungan sehingga terbentuk perekonomian yagn tangguh dan mandiri. 
6. Asas berwawasan lingkungan, yaitu asas pemberdayaan UMKM yang dilakukan dengan tetap memperhatikan dan mengutamakan perlindangan dan pemeliharaan lingkungan hidup.

7. Asas kemnadirian, yaitu asas pemberdayaan UMKM yang dilakukan dengan tetap menjaga dan mengedepankan potensi, kemampuan dan kemandirian UMKM

8. Asas keseimbangan kemajuan, yaitu asas pemberdayaan UMKM yang berupaya menjaga keseimbangan kemajuan ekonomi wilaya dalam kesatuan ekonomi nasional.

9. Asas kesatuan ekonomi nasional, adalah asas pemberdayaan UMKM yang merupakan bagian dari pembangunan kesatuan ekonomi nasional

\section{Prinsip dan tujuan pemberdayaan UMKM}

Berdasarkan BAB II, Pasal 4 dan Pasal 5 UU no. 20 tahun 2008 tentang UMKM, prinsip dan tujuan pembedayaan UMKM sebagai berikut;

1. Prinsip pemberdayaan UMKM
a. Penumbuhan kemandirian, kebersamaan dan kewirausahaan UMKM untuk ber-Karya dengan prakarsa sendiri
b. Mewujdukan kebijakan publik yang transparan, akuntabel dan berkeadilan
c. Pengembangan usaha berbasia potensi daerah dan berorientasi pasar sesuai dengan kompetensi UMKM
d. Peingkatan daya saing UMKM dan
e. Penyelenggaraan, perencanaan, pelaksanaan dan pengendalain secara terpadu

2. Tujuan pemberdayaan UMKM

a. Mewujudkan struktur perekonomian nasional yang seimbang, berkembang dan berkeadilan

b. Menumbukan dan mengembangkan kemampuan UMKM menjadi usaha yang tangguh dan mandiri dan

Meningkatkan peran UMKM dalam pembangunan daerah, penciptaan lapangan kerja, pemerataan pendapatan, pertumbuhan ekonomi dan pengentasan rakyat dan Kemiskinan.

\section{Asas, Prinsip dan Tujuan Pemberdayaan UMKM}

Wirausahawan harus memahami lebih dahulu mengenai Asas, Prinsip dan Tujuan Pemberdayaan UMKM, dimana ini akan membantu dalam proses kewirausahaan sehingga tidak adanya hambatan dalam mencapai suatu tujuan, (Leonardus Saiman, 2014) 


\section{Wirausahawan UMKM yang Sukses} adalah

(Kasali, 2012) Kiat-kiat pelaku usahawan yang dapat diambil secara empiris

1. Usaha apa pun selalu menghadapi perubahan-perubahan yang bersifat evolusioner dan revolusioner. Yang kerap ditakuti adalah perubahan yang rvolusioner karena sering kali terjadi secara mendadak. Padahal, perubahan yang revolusionerlah yang sering kali membuka mata kita. Semua pelaku usaha takut pada perubahan yang sifatnya revolusioner, yaitu perubahan yang berjalan sedikit demi sedikit, karena tidak disadari. Perubahan itu terjadi dari hari ke hari, tiba-tiba kita mendapati diri kita, usaha kita, hidup kita ,sudah tertinggal jauh di belakang karena tidak menyesuaikan diri. (Hendro, 2011), terdapat beberapa faktor yang menstimulus spirit of entrepreneurship, yaitu:

a. Evolusi Produk, Perubahan produk akan menimbulkan perubahan kebutuhan yang memunculkan sebuah peluang baru.

b. Evolusi Ilmu Pengetahuan, Perubahan ilmu pengetahuan akan menimbulkan inspirasi produk baru dan begitu seterusnya.

c. Perubahan Gaya hidup, selera dan hobi, Perubahan gaya hidup akan menimbulkan keinginan akan produk yang berbeda.

d. Perubahan Teknologi, Berkembangnya teknologi dan semakin canggihnya teknologi akan menciptakan produk, suasana dan gaya hidup yang berbeda.

e. Perubahan Budaya, Berkembangnya gaya hidup, pendapatan, selera, teknologi dan sebagainya akan mengubah budaya seseorang, sehingga hal ini mempengaruhi kebutuhan akan produk yang berbeda di setiap tempat.

f. Perubahan Struktur pemerintahan dan politik, Perubahan politik akan mempengaruhi perubahan struktur pemerintahan yang berujung pada perubahan peraturan, kebijkan dan arah perekonomian sehingga munculah gap kebutuhan akan produk yang lalu dan pasca perubahan.

g. Intrapreneurship, Kemampuan Intrapreneurship (entrepreneurship di dalam sebuah perusahaan internal) yang semakin baik dan kuat akan memunculkan gairah entrepreneur. Hal ini disebabkan karena kreativitas, inovasi, ketatnya persaingan, hasrat ingin tantangan yang lebih baru, perubahan organisasi, dan lain-lain. Jadi, Organisasi secara tidak langsung mengembangkan jiwa entrepreneurship seseorang.

(Justin G. Longenecker, 2001) konteks berubahnya bisnis berskala kecil, menghadirkan tantangan antara lain:

a. Pertumbuhan superstore, Jika anda memiliki toko yang kecil dan dimasuki oleh superstore modern, tak perlu berpikir panjang untuk menyadari bahwa anda berada dalam masalah besar. Meskipun perubahan dunia bisnis menancam kehidupan perusahaan dan bahkan menghancurkan, bisnis berskala kecil saat ini harus menghadapi tantangan yang ada dengan semangat wirausaha. Banyak perusahaan bertahan hidup jika mereka tampil bersaing.

b. Perluasan teknologi informasi dan internet. 
c. Timbulnya perekonomian global

2. Pentingnya Regenerasi. Para pelaku UKM selalu mengandalkan keluarga sebagai sumber penerus usaha. Keluarga yang dimaksud tentu saja buka hanya hubungan keluarga secara vertikal antara orngatua dan anak, tetapi juga antara paman dengan keponakan. Ini berarti sesungguhnya sumber daya untuk pengembangan usaha keluarga atau usaha kecil sangat terbatas. (Masitah, 2013) Melalui penelitian yang dilakukan secara kuantitatif empiris, bahwa Varibel peran keluarga dan praktik kewirausaahan secara simultan dan parsial berpengaruh signifikan terhadap kewirausahaan (uji-F) dan Variabel yang paling berpengaruh dalam sikap kewirausahaan adalah variabel praktek aplikasi kewirausahaan (Uji t), sehingga hal ini menjadikan pokok bagian penting untuk:

a. Peran keluarga dan praktik kewirausahaan harus lebih ditekankan secara intensif

b. Praktik kewirausahaan memberikan pengaruh yang paling dominan dan berpengaruh signifikan terhadap sikap kewirausahaan

c. Interaksi dan memperoleh wawasan pengalaman dari keluarga hal yang menjadi penting

(Rambat lupiyoadi, 2007) Hal-hal yang mempengaruhi kegagalan Usaha Kecil, paling tidak ada empat faktor yang ikut mendorong gagalnya suatu bisnis kecil. Pertama, banyak usaha kecil yang dikelola oleh manajer yang kurang mampu dan kurang berpengalaman dalam menjalankan tugasnya. Kedua, kurangnya dukungan dari pihak yang berhubungan. Sering setelah peresmian usaha dilakukan banyak wirausaha yang mendapat tawaran untuk menjalankan usaha baru, sehingga perhatiannya tidak dipusatkan pada usaha tersebut. Ketiga, masih lemahnya sistem kontrol/ pengawasan, dimana sistem pengontrolan yang lemah cenderung akan menyebabkan kerugian dan penggunaan sumber daya-sumber daya yang berlebihan. Terakhir adalah masalah kurangnya modal untuk menjalankan usahanya.

(Tambunan, 2002) bahwa hasil survey BPS terhadap wirausaha menunjukan bahwa masalah yang paling sering disebut adalah keterbatasan modal dan kesulitan dalam pemasaran. Salah satu hal yang menarik dari hasil survey ini adalah bahwa keterbatasan SDM dan teknologi modern ternyata tidak merupakan masalah yang serius bagi banyak wirausahawan.

3. Pentingnya entrepreneurship. Entrepreneurship adalah sebuah cara berpikir dan bertindak yang didasari oleh kemampuan melihat dan menangkap peluang. Suatu peluang hanya dapat ditangkap oleh mereka yang mempersiapkan diri pada bidang tersebut. Orang-orang yang mempersiapkan diri adalah orang yang mua bekerja keras dan membangun hubungan yang sangat luas.

Tidak dapat disangkal bahwa usaha kecil di Indonesia mengalami kendala permodalan. Tetapi, kendala ini lebih disebabkan oleh cara berpikir dan ketidakmengertian dalam berhubungan dengan sektor-sektor keuangan atau para pemilik modal. Untuk mendapatkan modal, diperlukan pencatatan yang dapat dipertanggungjawabkan dan disiplin dalam pengembalian. Ketidakpahaman inilah yang membuat banyak usaha kecil yang terkunci di dalam ruang usaha yang kecil dan gelap. (Kasmir, 2011) beberapa 
pertimbangan yang perlu diperhatikan apabila untuk memperoleh suatu modal adalah sebagai berikut:

a. Tujuan perusahaan, perusahaan perlu mempertimbangkan tujuan penggunaan pinjaman tersebut, apakah untuk modal investasi atau modal kerja, apakah sebagai modal utama atau hanya sekedar modal tambahan, apakah untuk kebutuhan yang mendesak atau tidak

b. Masa pengembalian modal, dalam jangka waktu tertentu pinjaman tersebut harus dikembalikan ke kreditor (bank). Bagi perusahaan jangka waktu pengembalian investasi juga perlu dipertimbangkan, sehingga tidak menjadi beban perushaan dan tidan mengganggu cash flow perushaan. Sebaiknya jangka waktu pinjaman disesuaikan dengan kebutuhan perusahaan.

c. Biaya yang dikeluarkan, faktor biaya yang harus dikeluarkan harus dipertimbangkan secara matang, misalnya biaya bunga, biaya administrasi, provisi dan komisi atau biaya lainnya. Hal ini penting karena biaya meruapakan komponen produksi yang akan menjadi beban perusahaan dalam menentukan harga jual dan laba. Besarnya tingkat suku bunga dan biaya lain yang dibebankan bank atas lembaga keuangan kepada nasabah berbeda-beda antara satu dengan lainnnya. Sebaiknya dipilih bank yang mampu memberikan biaya (bunga dan biaya lainnya) yang paling rendah (kompetitif) bagi perusahaan. Sekali lagi besarnya biaya yang dibebankan akan berakibat pada meningkatnya biaya operasi dan pada akhirnya dapat mengurangi keuntungan.

d. Estimasi keuntungan, besarnya keuntungan yang akan diperoleh pada masa-masa yang akan datang perlu menjadi pertimbangan. Estimasi keuntungan diperoleh dari selisih pendapatan dengan biaya dalam suatu periode tertentu. Besar kecil keuntungan sangat berperan dalam pengembalian dana suatu usaha.

e. Sumber godaan. Semua usaha kecil Indonesia di abad 21 ini menghadapi godaan besar dari sektor politik. Mereka akan mendapatkan tawaran untuk menjadi anggota atau pengurus partai politik, ikut dalam kompetisi untuk memperebutkan jabatan sebagai pejabat publik, baik mereka sendiri maupun keturunannya. Usaha yang sudah dirintis dengan sangat baik hendaknya jangan sampai terganggu oleh keinginan anada untuk mendaptakan kehormatan dalam jabatan-jabatan politik baik dipusat maupun di daerah terpencil.

f. Sifat usaha yang membentuk Cluster. Dimana-mana diseluruh dunia, usaha itu bersifat berkumpul. Seperti usaha penjualan tape singkong (tape gantung) di Purwakarta, mainan berbentuk buah-buahan di Cianjur, colenak di Pasar Lembang, sepatu di Cibaduyut, usaha bordir di Tasik, dodol di Garut, tahu di Sumedang, genteng di Jatiwangi, dan seterusnya. Di luar negeri pun demikian. Industri film di Amerika adanya di Hollywood sedangkan di India berkumpul di Bollywood. Demikian juga bisnis teknologi informasi, adanya di Silicon Valley, sementara kain sutra di Thailand. Hal ini sama seperti yang diungkapkan (Mukhammad K. Mawardi, 2010), pentingnya strategi kluster dalam pengembangan UKM, bahwa dengan sistem klustering, UKM akan dapat beroperasi secara efisien dan mendapat kemudahan dalam penguatan permodalan dari perbankan dan akhirnya memiliki daya saing tinggi, nilai 
strategisnya pendekatan kluster dalam mendongkrak nilai tambah UKM di pasar.

g. Keuletan. Modal utama seorang pengusaha kecil selain keujuran dan integritas adalah keuletan dan kerja keras. Hampir semua pengusaha yang kami temui memiliki self-discipline yang sangat kuat sehingga mereka percaya bahwa mereka harus bangun lebih cepat daripada matahari dan baru beristirahat setelah matahari terbenam. Dalam hal tertentu, ini bisa menjadi sumber bagi pengembangan usaha, tapi sekaligus bisa menjadi penghambat bagi kemajuan usaha. Dapat menjadi sumber kemajuan, karena membuat timbul. Tetapi, juga dapat menjadi hambatan kalau hal ini membuat mereka asyik dengan diri mereka sendiri sehingga lupa untuk bekerja dengan membangun sumber daya dari tenaga-tenaga di luar dirinya.

h. Peluang Berwirausaha, sering kita menghadapi permasalahan yang terkadang kita merasa tidak sanggup melaksanakannya. Namun sebenarnya bila kita tinjau lebih jauh direnungkan. Di balik permasalahan tersebut semua ada kemudahan atau peluang. Hanya saja yang harus kita sikapi, apakah kita memandang satu keadaan sebagai suatu masalah yang harus dihindari dan dijauhi atau sebagai peluang untuk dikejar dan ditangkap.

\section{METODE PENELITIAN}

(Sugiyono, 2013) Populasi adalah wilayah generalisasi yang terdiri atas: obyek/ subyek yang mempunyai kuantitas dan karakteristik tertentu yang ditetapkan oleh peneliti untuk dipelajari dan kemudian ditarik kesimpulannya. Jumlah populasi dalam penelitian ini adalah mahasiswa dari 3 Perguruan Tinggi yang memiliki mata kuliah Kewirausahaan yang terdapat di DKI Jakarta yaitu di Universitas Bakrie, Universitas Nasional, dan Universitas Prasetya Mulya, namun untuk sampel yang terakhir diganti menjadi Universitas Thamrin. (Sugiyono, 2013) Sampel menurut adalah bagian dari jumlah dan karakteristik yang dimiliki oleh populasi tersebut. Teknik sampling yang digunakan adalah Probability sampling yaitu Simple random sampling. Dimana jumlah sampel yang diberikan sebanyak 112 Mahasiswa dengan dilakukan taraf kesalahan 5\%.

Metode pengumpulan data yang dilakukan adalah sebagai berikut, Kuesioner, berupa pertanyaan-pertanyaan yang disusun untuk diisi oleh responden. Maksudnya adalah untuk memperoleh data primer berupa informasi secara tertulis langsung dari reponden mengenai variabel yang diteliti. Dokumentasi, yaitu mengumpulkan informasi dengan mempelajari sumber data tertulis untuk memperoleh data sekunder mengenai latar belakang dan data tertulis lainnya yang mendukung penelitian ini.

Skala pengukuran yang digunakan dalam pengukuran variabel penelitian ini yaitu menggunakan skala likert yang menggunakan data interval penilaian untuk setiap jawaban responden adalah 1 sampai 5. Interval jawaban respondan akan disesuaikan dengan pertanyaan yang diajukan. (Sugiyono, 2013) Skala likert ini berhubungan dengan pernyataan tentang sikap seseorang terhadap sesuatu, misalnya setuju-tidak setuju, senang-tidak senang dan baik-tidak baik.

\section{HASIL DAN PEMBAHASAN}

Hasil penelitian ini sudah terlaksana seratus persen (100\%) dari hasil penelitian yang dilakukan dibeberapa sampel yang sudah ditentukan. 
Sebanyak 112 Angket disebar secar acak kepada mahasiswa Universitas Nasional (UNAS) Jakarta, Universitas Bakrie Jakarta dan Universitas Thamrin Jakarta, Setiap Responden mengisi angket dengan benar dimana total yang terkumpul untuk angket sebanyak 64 sesuai dengan jumlah responden. Tabel 5.1 memperlihatkan dari 3 kampus yang berbeda dimana untuk Universitas Nasional mempunyai jumlah responden untuk Laki-laki sebanyak $47,06 \%$ dan Perempuan sebanyak 52,95\%, untuk Universitas Bakrie dimana Laki-laki sebanyak 36,67\% dan Perempuan sebanyak 63,33\% dan terakhir Universitas Thamrin dimana laki-laki sebanyak 43,75\% dan Perempuan sebanyak 56,25\%

Tabel 5.1 Karakteristik Responden

\begin{tabular}{lcc}
\hline \multicolumn{1}{c}{ Karakteristik Responden } & Jumlah Responden & Presentase \\
\hline Universitas Nasional Jakarta & & \\
Laki-laki (L) & 16 & $47,06 \%$ \\
Perempuan (P) & 18 & $52,94 \%$ \\
Universitas Bakrie Jakarta & 11 & $36,67 \%$ \\
Laki-laki (L) & 19 & $63,33 \%$ \\
Perempuan (P) & & \\
Universitas Thamrin Jakarta & 21 & $43,75 \%$ \\
Laki-laki (L) & 27 & $56,25 \%$ \\
Perempuan (P) & & \\
\hline
\end{tabular}

\section{Validitas Universitas Nasional Universitas Bakrie dan Universitas Thamrin Jakarta}

Secara simultan menunjukan hasil uji validitas indikator kiat wirausaha yang sukses dengan menggunakan Pearson Correlation. Hasil Uji Validitas menunjukan bahwa semua indikator memiliki nilai signifikan kurang dari 0.05 sehingga dinyatakan valid dalam mengukur Kiat wirausahawan yang sukses

Menunjukan hasil validitas indikator Peluang Mahasiswa untuk Berwirausaha dengan menggunakan Pearson Correlation . Hasil Uji Validits menunjukkan bahwa semua indikator memiliki nilai signifikan kurang dari 0,05 sehingga dinyatakan valid dalam mengukur Peluang Mahasiswa untuk Berwirausaha.

\section{Uji Reliabilitas Universitas Nasional Jakarta}

Hair et al (2010) mendefinisikan reliabilitas sebagai penilaian dari tingkat konsistensi antra beberapa pengukuran variabel. Penelitian ini menilai konsistensi seluruh skala dengan alpha Cronbach dan keandalan keseluruhan dari setiap indikator. Pada tabel 5.2 Terlihat tingkat keandalan berdasarkan nilai alpha Cronbach, dimana tertampil dari Kurang andal sampai dengan Sangat andal, terlampir pada tabel 5.2 Dibawah:

Tabel 5.2 Tingkat keandalan Berdasarkan Nilai Alpha Cronbach

\begin{tabular}{|c|c|}
\hline NILAI ALPHA CRONBACH & TINGKAT KEANDALA \\
\hline $0,9-0,20$ & Kurang Andal \\
\hline$>0,20-0,40$ & Agak Andal \\
\hline$>0,40-0,60$ & Cukup Andal \\
\hline$>0,60-0,80$ & Andal \\
\hline$>0,80-1,00$ & Sangat Andal \\
\hline
\end{tabular}


Variabel Kiat Wirausaha yang sukses diperoleh nilai alpa Cronbach sebesar 0,691, nilai tersebut masuk dalam kategori Andal, jadi dapat disimpulkan bahwa variabel Kiat Wirausaha yang Sukses reliabel.

Sama dengan halnya padaTabel 10 (Lihat lampiran). Peluang mahasiswa berwirausaha masuk dalam kategori Sangat Andal yaitu 0,863 jadi dapat disimpulkan bahwa Peluang Mahasiswa untuk berwirausaha reliabel.

\section{Uji Reliabilitas Universitas Bakrie Jakarta}

Kiat Wirausaha yang sukses masuk dalam kategori Sangat Andal yaitu 0,888 jadi dapat disimpulkan Kiat Wirausaha yang sukses reliabel dan Juga untuk Peluang Mahasiswa untuk Wirausaha 0,871 masuk dalam kategori Sangat Andal, jadi dapat disimpulkan bahwa Peluang Mahasiswa untuk berwirausaha Reliabel

\section{Uji Reliabilitas Universitas Thamrin Jakarta}

Kiat Wirausaha yang sukses masuk dalam kategori Sangat Andal yaitu 0,621 jadi dapat disimpulkan Kiat Wirausaha yang sukses reliabel dan Juga Peluang Mahasiswa untuk Wirausaha 0,846 masuk dalam kategori Sangat Andal, jadi dapat disimpulkan bahwa Peluang Mahasiswa untuk berwirausaha Reliabel

\section{Hubungan Antara Kiat Wirausahawan Yang Sukses Terhadap Peluang Mahasiswa Untuk Berwirausaha Universitas Nasional}

Analisis dari Correlations pada Menghasilkan point-point seperti berikut:

1. Menunjukan bahwa jumlah responden sebanyak 34. Nilai rata-rata Kiat kewirausahaan yang sukses sebesar 31,64 dan Nilai rata-rata peluang usaha sebesar 34,22

2. Correlations, menunjukan bahwa hubungan (korelasi) antara Kiat Wiruusahawan yang sukses terhadap Peluang Mahasiswa untuk Berwirausaha Kuat Positif, yaitu 0,691, arti positif adalah hubungan antara Variabel X dan Y searah, maksudnya searah disini adalah Semakin lama hubungan Kiat Kewirausahaan yang sukses dengan Peluang Mahasiswa untuk berwirausaha, maka semakin besar Peluanga Mahasiswa untuk berwirausaha. Begitu Juga sebaliknya semakin rendah hubungan Kiat Kewirausahaan yang sukses dengan Peluang Mahasiswa untuk berwirausaha, maka semakin kecil juga Peluang Mahasiswa untuk berwirausaha.

\section{Hubungan Antara Kiat Wirausahawan Yang Sukses Terhadap Peluang Mahasiswa Untuk Berwirausaha Universitas Bakrie}

Analisis dari Correlations Menghasilkan point-point seperti berikut:

1) Menunjukan bahwa jumlah responden sebanyak 30. Nilai rata-rata Kiat kewirausahaan yang sukses sebesar 32,3 dan Nilai rata-rata peluang usaha sebesar 36,9

2) Correlations, menunjukan bahwa hubungan (korelasi) antara Kiat Wiruusahawan yang sukses terhadap Peluang Mahasiswa untuk Berwirausaha Sangat Kuat Positif, yaitu 0,810, arti positif adalah hubungan antara Variabel X dan Y searah, maksudnya searah disini adalah Semakin lama hubungan Kiat Kewirausahaan yang sukses dengan Peluang Mahasiswa untuk berwirausaha, maka semakin besar Peluanga Mahasiswa untuk berwirausaha. Begitu Juga sebaliknya semakin rendah hubungan Kiat Kewirausahaan yang sukses dengan 
Peluang Mahasiswa untuk berwirausaha, maka semakin kecil juga Peluang Mahasiswa untuk berwirausaha.

Hubungan Antara Kiat Wirausahawan yang sukses terhadap peluang mahasiswa untuk Berwirausaha Universitas Thamrin

Analisis dari Correlations pada Tabel 16 (Lihat lampiran) menghasilkan pointpoint seperti berikut:

1. Menunjukan bahwa jumlah responden sebanyak 48. Nilai rata-rata Kiat kewirausahaan yang sukses sebesar 31,2 dan Nilai rata-rata peluang usaha sebesar 32,9

2. Correlations, menunjukan bahwa hubungan (korelasi) antara Kiat Wiruusahawan yang sukses terhadap Peluang Mahasiswa untuk Berwirausaha Sangat Kuat Positif, yaitu 0,433, arti positif adalah hubungan antara Variabel X dan Y searah, maksudnya searah disini adalah Semakin lama hubungan Kiat Kewirausahaan yang sukses dengan Peluang Mahasiswa untuk berwirausaha, maka semakin besar Peluanga Mahasiswa untuk berwirausaha. Begitu Juga sebaliknya semakin rendah hubungan Kiat Kewirausahaan yang sukses dengan Peluang Mahasiswa untuk berwirausaha, maka semakin kecil juga Peluang Mahasiswa untuk berwirausaha.

\section{Pengaruh Efektif (Regresi) Kiat Wirausahawan yang sukses terhadap peluang mahasiswa Berwirausaha Universitas Nasional} 1) .

Dari tabel Anova (b) dapat dilihat dan dianalisis bahwa

$\mathrm{H}_{0}$ : model regresi linier sederhana tidak dapat digunakan untuk memprediksi Kiat kewirausahaan yang sukses terhadap peluang mahasiswa untuk berwirausaha

$\mathrm{H}_{\mathrm{a}}$ : model regresi linier sederhana dapat digunakan untuk memprediksi Kiat kewirausahaan yang sukses terhadap peluang mahasiswa untuk berwirausaha

2) Kaidah pengujian

a) Berdasarkan perbandingan antara $F_{\text {hitung }}$ dan $F_{\text {tabel }}$, maka

jika $\mathrm{F}_{\text {hitung }} \leq \mathrm{F}_{\text {tabel }}$, maka $\mathrm{H}_{0}$ diterima

Jika $\mathrm{F}_{\text {hitung }} \geq \mathrm{F}_{\text {tabel }}$ maka $\mathrm{H}_{0}$ ditolak

Dimana: Nilai $F_{\text {hitung }}$ dari Tabel Anova sebesar 29,235 dan nilai $F_{\text {tabel }}=4,08$

b) Berdasarkan nilai Probabilitas

Jika Probabilitas (sig) $>\alpha$ maka $\mathrm{H}_{0}$ diterima

Jika Probalbilitas (sig) $<\alpha$ maka $\mathrm{H}_{0}$ ditolak

Dimana: Dari tabel Anova nilai probabilitas $(\mathrm{Sig})=0,00$ dan nilai taraf sign $\alpha=0,05$

3) Membandingkan $F_{\text {tabel }}$ dari $F_{\text {hitung }}$ serta sig dan $\alpha$

Ternyata $\mathrm{F}_{\text {hitung }}=29,235>\mathrm{F}_{\text {tabel }}=4,08$ maka $\mathrm{H}_{0}$ ditolak, ternyata $0,00<0,05$ maka $\mathrm{H}_{0}$ ditolak

4) Keputusannya

Model regresi linier sederhana dapat digunakan untuk memprediksi Peluang mahasiswa untuk berwirausaha yang dipengaruhi oleh Kiat kewirausahaan yang sukses

Pengaruh Efektif (Regresi) Kiat Wirausahawan yang Sukses terhadap Peluang Mahasiswa Berwirausaha Universitas Bakrie 
T. Ardiansyah, P. Ariwibowo, dan K. Umam / Journal of Applied Business and Economics Vol. 4 No. 4 (Jun 2018) 336-349

1).

Dari tabel Anova (b) dapat dilihat dan dianalisis bahwa

$\mathrm{H}_{0}$ : model regresi linier sederhana tidak dapat digunakan untuk memprediksi Kiat kewirausahaan yang sukses terhadap peluang mahasiswa untuk berwirausaha

$\mathrm{H}_{\mathrm{a}}$ : model regresi linier sederhana dapat digunakan untuk memprediksi Kiat kewirausahaan yang sukses terhadap peluang mahasiswa untuk berwirausaha

2) Kaidah pengujian

a) Berdasarkan perbandingan antara $F_{\text {hitung }}$ dan $F_{\text {tabel }}$, maka

jika $\mathrm{F}_{\text {hitung }} \leq \mathrm{F}_{\text {tabel }}$, maka $\mathrm{H}_{0}$ diterima

Jika $\mathrm{F}_{\text {hitung }} \geq \mathrm{F}_{\text {tabel }}$ maka $\mathrm{H}_{0}$ ditolak

Dimana: Nilai $F_{\text {hitung }}$ dari Tabel Anova sebesar 5,146 dan nilai $F_{\text {tabel }}=4,08$

b) Berdasarkan nilai Probabilitas

Jika Probabilitas (sig) $>\alpha$ maka $\mathrm{H}_{0}$ diterima

Jika Probalbilitas (sig) $<\alpha$ maka $\mathrm{H}_{0}$ ditolak

Dimana: Dari tabel Anova nilai probabilitas $(\mathrm{Sig})=0,00$ dan nilai taraf sign $\alpha=0,05$

3) Membanding Ftabel dari Fhitung serta sig dan $\alpha$,

Ternyata $\mathrm{F}_{\text {hitung }}=29,235>\mathrm{F}_{\text {tabel }}=4,08$ maka $\mathrm{H}_{0}$ ditolak, ternyata $0,00<0,05$ maka $\mathrm{H}_{0}$ ditolak

4) Keputusannya

Model regresi linier sederhana dapat digunakan untuk memprediksi Peluang Mahasiswa untuk Berwirausaha yang dipengaruhi oleh Kiat kewirausahaan yang Sukses

\section{Pengaruh Efektif (Regresi) Kiat Wirausahawan Yang Sukses Terhadap Peluang Mahasiswa Berwirausaha Universitas Thamrin}

Dari tabel Anova dan dianalisis bahwa

1) .

$\mathrm{H}_{0}$ : model regresi linier sederhana tidak dapat digunakan untuk memprediksi Kiat kewirausahaan yang sukses terhadap peluang mahasiswa untuk berwirausaha

$\mathrm{H}_{\mathrm{a}}$ : model rgresi linier sederhana dapat digunakan untuk memprediksi Kiat kewirausahaan yang sukses terhadap peluang mahasiswa untuk berwirausaha

2) Kaidah pengujian

a) Berdasarkan perbandingan antara $F_{\text {hitung }}$ dan $F_{\text {tabel }}$, maka

jika $\mathrm{F}_{\text {hitung }} \leq \mathrm{F}_{\text {tabel }}$, maka $\mathrm{H}_{0}$ diterima

Jika $\mathrm{F}_{\text {hitung }} \geq \mathrm{F}_{\text {tabel }}$ maka $\mathrm{H}_{0}$ ditolak

Dimana: Nilai $F_{\text {hitung }}$ dari Tabel Anova sebesar 10,589 dan nilai $F_{\text {tabel }}=4,05$

b) Berdasarkan nilai Probabilitas

Jika Probabilitas (sig) $>\alpha$ maka $\mathrm{H}_{0}$ diterima

Jika Probalbilitas (sig) $<\alpha$ maka $\mathrm{H}_{0}$ ditolak

Dimana: Dari tabel Anova nilai probabilitas $(\mathrm{Sig})=0,00$ dan nilai taraf sign $\alpha=0,05$

3) Membanding Ftabel dari Fhitung serta sig dan $\alpha$, 
Ternyata $\mathrm{F}_{\text {hitung }}=10,589>\mathrm{F}_{\text {tabel }}=4,05$ maka $\mathrm{H}_{0}$ ditolak, ternyata $0,002<0,05$ maka $\mathrm{H}_{0}$ ditolak

4) Keputusannya

Model regresi linier sederhana dapat digunakan untuk memprediksi Peluang mahasiswa untuk berwirausaha yang dipengaruhi oleh Kiat kewirausahaan yang sukses

\section{E. SIMPULAN}

Berdasarkan hasil dari penelitian dapat disimpulkan sebagai berikut:

1. Di Univeristas Bakrie Jakarta Kiat Wirausaha yang sukses masuk dalam kategori Sangat Andal, dengan nilai alpa croncbach sebesar 0.888 dapat disimpulkan Kiat Wirausaha yang sukses reliabel termasuk juga. Peluang Mahasiswa untuk Wirausaha 0,871 masuk dalam kategori Sangat Andal, disimpulkan bahwa Peluang Mahasiswa untuk berwirausaha Reliabel

2. Di Univeristas Thamrin Jakarta Kiat Wirausaha yang sukses masuk dalam kategori Sangat Andal, dengan nilai alpa croncbach sebesar 0.621 dapat disimpulkan Kiat Wirausaha yang sukses reliabel termasuk juga. Peluang Mahasiswa untuk Wirausaha 0,846 masuk dalam kategori Sangat Andal, disimpulkan bahwa Peluang Mahasiswa untuk berwirausaha Reliabel

3. Dari hasil perbandingan antara nilai Sig dan $\alpha$ diperoleh bahwa, hasil Sig $=0,00<\alpha=0,05$, sehingga keputusannya $\mathrm{H}_{0}$ ditolak yaitu ada hubungan yang signifikan hubungan antara Kiat Kewirausahaan yang sukses dengan Peluang Mahasiswa untuk berwirausaha di Universitas Nasional 
T. Ardiansyah, P. Ariwibowo, dan K. Umam / Journal of Applied Business and Economics Vol. 4 No. 4 (Jun 2018) 336-349

\section{DAFTAR PUSTAKA}

Hendro. (2011). Dasar-dasar Kewirausahaan (I). Jakarta: Erlangga.

Justin G. Longenecker, C. W. M. dan J. W. P. (2001). Kewirausahaan, Manajemen Usaha Kecil. Jakarta: Salemba Empat.

Kasali, R. (2012). Cracking Entrepreneurs, inilah para crackers lokal yang tak ada matinya, Jakarta: Gramedia.

Kasmir. (2011). Kewirausahaan. Jakarta: Rajagrafindo Persada.

Leonardus Saiman. (2014). Kewirausahaan: Teori, Praktik, dan Kasus-kasus (II). Jakarta: Salemba Empat.

Masitah, D. dan E. M. (2013). Pengaruh peran keluarga dan praktik kewirausahaan dalam membentuk sikap kewirausahaan mahasiswa pendidikan ekonomi angkatan tahun 2009-2010 fakultas ekonomi, Universitas Negeri Surabaya. Jurnal Pendidikan Tata Niaga (JPTN) Vol. 1 No.3.

Mukhammad K. Mawardi. (2010). Kluster Usaha Kecil Menengah ( UKM ) di Indonesia. emkamawardi.blogspot.com. Retrieved from http://emkamawardi.blogspot.com/2010/12/kluster-usaha-kecil-menengah-ukmdi.html

Rambat lupiyoadi. (2007). Entrepreneurship, form mindset to strategy. Jakarta: FE UI.

Robert D. Hisrich, Michael P. Peters, D. A. S. (2008). Entrepreneurship kewirausahaan (7th ed.). Jakarta: Salemba Empat.

Sugiyono. (2013). Metode Penelitian Manajemen. Bandung: AlfaBeta.

Tambunan, T. T. H. (2002). Usaha kecil dan Menengah di Indonesia, beberapa isu penting. Jakarta: Salemba Empat. 